\title{
Optimalisasi Ekspor Produk Ekonomi Kreatif Indonesia Menuju Peningkatan Dayasaing
}

\author{
Sugiyono Madelan \\ Master of Management, Postgraduate Faculty, Mercu Buana University, \\ Jakarta 11480, Indonesia \\ sugiyono@mercubuana.ac.id
}

\begin{abstract}
Indonesia's creative economy product exports have not been optimal. The purpose of this study is to optimize the goals of creative economic development in Indonesia. This research was conducted using secondary time series data for the period 2010-2017. The research method uses linear programming and goal programming. The results showed that exports of creative economy products responded to an increase in export selling prices based on the demand behavior of the exports of creative economy products. The factor of export competitiveness of Indonesia 's creative economy products lies in the use of cheaper labor costs. Exports of creative economy products do not automatically increase, if the education level of the workforce increases, but rather comes from an increase in creativity. Fashion products are efficient products compared to producing exports of craft products and culinary products. Finally, the development of the creative economy is more optimal for the purpose of increasing exports of creative economy products than for the purpose of increasing employment, namely by producing fashion products.
\end{abstract}

Keywords - Optimization; creative economy; fashion products.

\begin{abstract}
ABSTRAK
Ekspor produk ekonomi kreatif Indonesia belum optimal. Tujuan dari penelitian ini adalah untuk mengoptimalkan tujuan pembangunan ekonomi kreatif di Indonesia. Penelitian ini dilakukan dengan menggunakan data deret waktu sekunder untuk periode 2010-2017. Metode penelitian menggunakan program linier dan goal programming. Hasil penelitian menunjukkan bahwa ekspor produk ekonomi kreatif merespons peningkatan harga jual ekspor berdasarkan perilaku permintaan jumlah ekspor produk ekonomi kreatif. Faktor daya saing ekspor produk ekonomi kreatif Indonesia terletak pada pemanfaatan upah tenaga kerja yang lebih murah. Ekspor produk ekonomi kreatif tidak secara otomatis meningkat, jika tingkat pendidikan tenaga kerja meningkat, tetapi peningkatan ekspor produk ekonomi kreatif lebih berasal dari peningkatan kreativitas. Produk fashion adalah produk yang efisien dibandingkan dengan menghasilkan ekspor produk kriya dan produk kuliner. Akhirnya, pengembangan ekonomi kreatif lebih optimal untuk tujuan meningkatkan ekspor produk ekonomi kreatif dibandingkan untuk mencapai tujuan meningkatkan lapangan kerja dari memproduksi produk fashion.
\end{abstract}

Kata kunci - Optimisasi; ekonomi kreatif; produk fashion.

\section{PENDAHULUAN}

Ekonomi kreatif telah tumbuh dan berkembang berawal dari hasil kreativitas sumberdaya manusia. Kreativitas yang berbasiskan pada ide-ide baru. Kreativitas yang diharapkan mampu menggerakkan perekonomian suatu bangsa. Peranan ekonomi kreatif dalam pembentukan Produk Domestik Bruto (PDB) sebesar Rp 784,82 triliun tahun 2014. Peran ekonomi kreatif meningkat menjadi Rp 852,24 triliun tahun 2015 (Badan Ekonomi Kreatif, 2017). Peran tersebut berada pada posisi sebesar 7,38 persen terhadap PDB pada tahun 2015. Peran yang cukup besar untuk diperhitungkan atas perkembangan awal pada perekonomian nasional. 
Ekonomi kreatif dewasa ini di Indonesia telah ditumbuhkembangkan dari berbagai subsektor, yaitu aplikasi dan game developer, arsitektur, desain interior, desain komunikasi visual, desain produk, fashion, film, animasi, dan video, fotografi, kriya, kuliner, musik, penerbitan, periklanan, seni pertunjukan, seni rupa, dan televisi dan radio. Dalam perkembangnnya, hanya tiga subsektor dari ekonomi kreatif yang berperan nyata pada Produk Domestik Bruto (PDB), yaitu kuliner sebesar 41,69 persen, fashion sebesar 18,15 persen, dan kriya sebesar 15,70 persen pada tahun 2015 (Badan Ekonomi Kreatif, 2017). Sementara itu subsektor yang lain dari ekonomi kreatif belum berkembang secara optimal dengan peranan kurang dari dua digit terhadap PDB. Kondisi peran ekonomi kreatif per subsektor yang seperti ini terhadap PDB berbeda dengan peran ekspor produk ekonomi kreatif. Subsektor kuliner mempunyai peran pertama dalam PDB, akan tetapi subsektor fashion mempunyai peran pertama terhadap ekspor produk ekonomi kreatif Indonesia. Perbedaan kedua peran tersebut antara mengutamakan ekspor ataukah PDB itu memerlukan kejelasan tentang manakah optimalisasi prioritas tujuan dari pembangunan ekonomi kreatif.

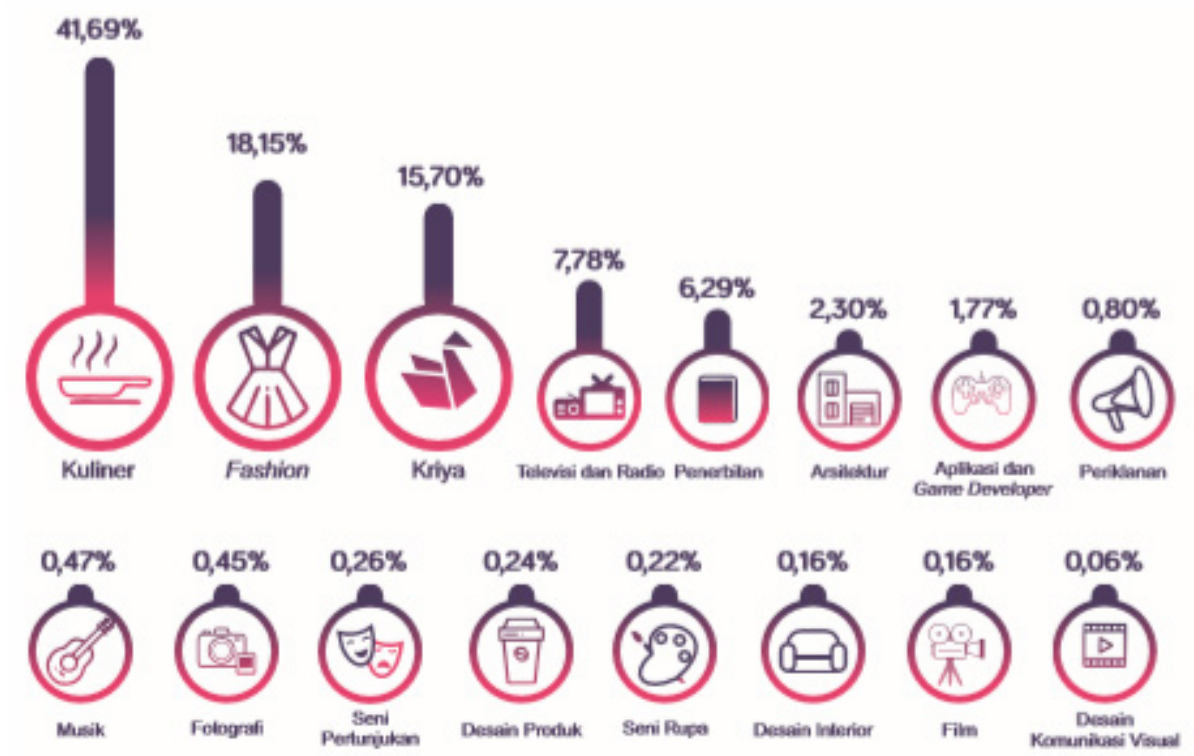

Gambar 1. Peran Ekonomi Kreatif terhadap Produk Domestik Bruto Nasional Tahun 2016 (Persen) (Sumber: Badan Ekonomi Kreatif, 2017)

Yang menarik dari produk ekonomi kreatif adalah adanya kegiatan pemasaran ekspor. Peran ekspor ekonomi kreatif sebesar 18,2 miliar dolar AS tahun 2014 meningkat menjadi 19,4 miliar dolar AS tahun 2015 (Badan Ekonomi Kreatif, 2017) sekalipun nomenklatur sektor ekonomi kreatif masih relatif baru dikembangkan di Indonesia. Berdasarkan pemasaran ekspor, subsektor ekonomi kreatif yang diekspor secara berturut-turut dari terbesar ke terkecil adalah produk fashion dengan pangsa ekspor sebesar 56 persen, kriya sebesar 37 persen, dan kuliner sebesar 6 persen.

Berdasarkan data tersebut terinformasikan bahwa pengembangan subsektor komoditi pada ekonomi kreatif belum optimal. Hanya terdapat tiga subsektor dari sektor ekonomi kreatif yang secara nyata berorientasi ekspor. Sementara itu produksi ekonomi kreatif berbasiskan pada kreativitas sumberdaya manusia. Implikasi dari basis kreativitas adalah faktor upah tenaga kerja berperan besar sebagai penentu terhadap produksi produkproduk ekonomi kreatif. Kondisi kreativitas tenaga kerja yang seperti ini mencerminkan keberadaan input pada upah tenaga kerja dan kapasitas pendidikan, maupun harga jual output produk ekonomi kreatif yang menjadi penentu produksi ekspor. Perubahan dari kondisi input dan harga jual output tersebut berperan terhadap jumlah produksi produk ekonomi kreatif. Disamping itu efisiensi tujuan ekspor dapat mempunyai kepentingan prioritas yang berbeda dengan prioritas penyerapan tenaga kerja, yaitu ketika pemerintah dihadapkan pada pilihan untuk mengutamakan ekspor subsektor produk fashion, kuliner, ataukah kriya. Oleh karena itu perlu disusun prioritas tujuan pembangunan ekonomi kreatif berdasarkan pendekatan prioritas per subsektor. 
Tabel 1. Perkembangan Nilai Ekspor Ekonomi Kreatif Indonesia Tahun 2010-2016 (Ribu US\$)

\begin{tabular}{|c|c|c|c|c|c|c|c|}
\hline Subsektor & 2010 & 2011 & 2012 & 2013 & 2014 & 2015 & 2016 \\
\hline (1) & (2) & (3) & (4) & (5) & (6) & $(7)$ & (8) \\
\hline Film, Animasi, Video & 0,0 & 2,0 & 0,0 & 0,0 & 0,0 & 0,1 & 1,2 \\
\hline Kriya & 4294196,8 & 4390189,6 & 4358484,7 & 4282512,5 & 6363369,8 & 7264504,8 & 7797661,1 \\
\hline Kuliner & 594239,5 & 863166,3 & 960895,4 & 956934,0 & 1081180,1 & 1178955,6 & 1260503,6 \\
\hline Musik & 14,6 & 2,5 & 20,4 & 56,9 & 10,6 & 29,0 & 14,5 \\
\hline Fashion & 8584325,1 & 10356882,4 & 10084407,5 & 10593408,8 & 10698835,3 & 10895217,7 & 10901481,5 \\
\hline Penerbitan & 28602,7 & 22210,7 & 21200,0 & 27159,6 & 15983,6 & 22334,5 & 26166,8 \\
\hline Seni Rupa & 5631,9 & 8943,7 & 14573,6 & 10556,6 & 5550,6 & 3035,7 & 3039,9 \\
\hline
\end{tabular}

Sumber: Dokumen PEB dan Non-PEB, diolah

Berdasarkan identifikasi masalah ketidakoptimalan pengembangan ekspor produk ekonomi kreatif di Indonesia tersebut di atas, maka disusun rumusan masalah sebagai berikut:

1) Bagaimana sensitivitas dari optimalisasi ekspor produk ekonomi kreatif ke pasar internasional yang mempunyai daya saing produk yang tinggi?

2) Bagaimanakah sensitivitas optimalisasi tujuan pemrograman (goal programming) antara tujuan ekspor dan tujuan penyerapan tenaga kerja pada sektor ekonomi kreatif di Indonesia sebagaimana tercermin pada prioritas jumlah ekspor subsector fashion, kuliner, ataukah kriya?

Penelitian pengembangan dayasaing produk ekonomi kreatifini dilakukan dimaksudkan untuk mensukseskan penumbuhkembangan produk ekonomi kreatif di Indonesia. Tujuan khusus penelitian ini adalah sebagai berikut:

1) Untuk menganalisis sensitivitas optimalisasi ekspor produk ekonomi kreatif ke pasar internasional yang mempunyai daya saing produk yang tinggi.

2) Untuk menganalisis sensitivitas optimalisasi tujuan pemrograman (goal programming) antara tujuan ekspor dan tujuan penyerapan tenaga kerja pada sektor ekonomi kreatif di Indonesia sebagaimana tercermin pada prioritas jumlah ekspor subsector fashion, kuliner, ataukah kriya di Indonesia.

Program linier adalah suatu teknik aplikasi matematika dalam menentukan pemecahan masalah, yang bertujuan untuk memaksimumkan atau meminimumkan sesuatu yang dibatasi oleh kendala-kendala tertentu. Contoh maksimisasi antara lain adalah keuntungan, produksi, manfaat, kecepatan, dan percepatan. Contoh minimisasi adalah biaya, waktu, dan jarak.

Pengertian program linier menurut Heizer dan Rander (2005) adalah sebuah teknik matematik yang didesain untuk membantu para manajer operasi dalam merencanakan dan membuat keputusan yang diperlukan untuk mengalokasikan sumber daya. Menurut Dimyati et.al (2006), program linier adalah perencanaan kegiatan untuk memperoleh suatu hasil yang optimum, yaitu suatu hasil yang mencapai tujuan terbaik diantara seluruh alternatif yang layak.

Yang baru pada posisi penelitian ini adalah penggunaan tingkat pendidikan pada model optimalisasi kinerja ekspor ekonomi kreatif. Disamping itu penggunaan tenaga kerja atas dasar white collar dan blue collar, serta skenario peningkatan kapasitas pendidikan tenaga kerja pada model optimalisasi nilai ekspor ekonomi kreatif berdasarkan pada tiga subsektor, yaitu produk fashion, produk kuliner, dan produk kriya. Penggunaan skenario simulasi peningkatan upah tenaga kerja untuk melihat keberadaan daya saing ekspor produk ekonomi kreatif di Indonesia, maupun untuk mengetahui prioritas goal programming per subsektor ekonomi kreatif dalam pengembangan ekspor dan penyerapan tenaga kerja.

Fathurrahman dan Huseini (2016) mengatakan bahwa ekonomi kreatif di Indonesia yang memiliki keunggulan kompetitif bersifat sementara, yaitu musik kreatif ekonomi, aplikasi digital \& permainan interaktif. Selanjutnya ekonomi kreatif yang memiliki keunggulan kompetitif belum dioptimalkan, yaitu: kuliner dan fashion ekonomi kreatif. Skavronska (2017) menyatakan bahwa ekonomi kreatif di Ukraina dikembangkan berdasarkan pertimbangan dari aspek manfaat ekonomi, sosial, kreatif dan budaya, serta menjaga dan mengembangkan bakat 
kreatif. Aspek budaya keterbukaan dijadikan sebagai pembentuk ekosistem kreatif di Ukraina.

Kontrimeine dan Meilnikas (2017) menyatakan bahwa pertumbuhan dan perkembangan industri kreatif di negara berkembang dengan mempertimbangkan tantangan globalisasi ekonomi, khususnya pada ekspor produk kreatif. Dunska dan Marcinkevica (2017) mengatakan bahwa tingkat inovasi dan produktivitas tenaga kerja penduduk Latvia untuk mengembangkan ekonomi kreatif lebih rendah dibandingkan negara maju di Eropa. Potts (2009) mengatakan bahwa penggabungan industri kreatif ke dalam model evolusi ekonomi akan mengisi kesenjangan teknologi sosial dari kemunculan, adopsi, difusi, dan retensi inovasi. Septri dan Krisnandi (2019) mengatakan bahwa teknologi big data digunakan pada pengembangan ekonomi kreatif di Indonesia.

Sukma, Hartono, dan Prihawantoro (2018) mengatakan bahwa ekspor fashion Indonesia meningkatkan nilai tambah nasional sebesar $0,06 \%$; pendapatan masyarakat $0,06 \%$ dan pekerjaan $0,11 \%$. Ekspor kerajinan Indonesia meningkatkan nilai nasional yang ditambahkan sebesar $0,05 \%$; pendapatan sebesar $0,05 \%$ dan pekerjaan sebesar 0,11\%. Daubaraite dan Startiene (2015) mengatakan bahwa pendanaan ekonomi kreatif dilandasi oleh peran ekonomi kreatif terhadap perekonomian nasional. Belete (2016) mengatakan bahwa industri hak cipta berperan terhadap perekonomian berdasarkan sudut pandang pembangunan berkelanjutan di Ethiopia. Skavronska (2017) mengatakan bahwa industri kreatif Ukraina perlu didorong menggunakan promosi "budaya keterbukaan" untuk membentuk ekosistem kreatif.

\section{METODE PENELITIAN}

\section{Desain Penelitian}

Desain penelitian menggunakan program linier. Hubungan yang digunakan merupakan hubungan sebab akibat antara fungsi kendala dengan fungsi tujuan dalam pemodelan.

\section{Data, Sumber Data, Metode Pengumpulan dan Metoda Pengolahan Data}

Data yang digunakan adalah data sekunder. Data dikumpulkan dari Badan Pusat Statistik Indonesia dan Badan Ekonomi Kreatif urutan waktu terbaru tahun 2010-2017. Data dikumpulkan dengan menggunakan metoda eksplorasi. Data diolah menggunakan software Lingo versi 11 (Lindo Systems Inc., 2008).

\section{Metode Analisis dan Interpretasi Data}

Metode analisis yang digunakan adalah riset operasi Linear Programming menggunakan maksimisasi model. Metoda interpretasi data menggunakan analisis kuantitatif berdasarkan pendekatan statistik deskriptif.

\section{Penyusunan Model Optimalisasi}

Model optimalisasi nilai ekspor produk ekonomi kreatif Indonesia disusun model awal sebagai berikut:

! OPTIMALISASI NILAI EKSPOR PRODUK EKONOMI KREATIF INDONESIA TAHUN 2015-2016;

\section{MAX $=7.26 / 1.38 *$ KRIYA5 + 7.8/1.25*KRIYA6 $+1.18 / 0.47 *$ KULINER5 \\ $+1.26 / 0.5 *$ KULINER6 + 10.9/0.65*FASHION5 + 10.9/0.64*FASHION6;}

Variabel adalah nama subsektor pada ekonomi kreatif, yaitu jumlah ekspor produk kriya, kuliner, dan fashion. Angka koefisien di depan variabel adalah harga ekspor (ribu dollar AS FOB per ton), yaitu rasio antara nilai ekspor (miliar dollar AS FOB) dan berat ekspor (juta ton). Kode 5 di depan nama variabel adalah data tahun 2015. Kode 6 di depan nama variabel adalah data tahun 2016.

\section{! MODAL KERJA;}

$1.44 *$ KRIYA5 + $1.41 *$ KULINER5 + 1.53*FASHION5 $<=15959590 * 1.59$;

$2.01 *$ KRIYA6 $+1.79 *$ KULINER6 + 2.09*FASHION6 $<=16909690 * 2.06$;

Angka koefisien di depan variabel adalah upah tenaga kerja (Rp Juta). Angka di sisi kanan pertidaksamaan adalah jumlah tenaga kerja ekonomi kreatif (orang) dikalikan upah tenaga kerja (Rp juta).

! PENDIDIKAN PEKERJA SMP KE BAWAH;

$1.16 *$ KRIYA5 + 1.06*KULINER5 + 1.44*FASHION5 $<=15959590 * 0.5905$

$1.66 *$ KRIYA $6+1.49 *$ KULINER6 + 1.91*FASHION6 <= 16909690*0.5905;

Angka koefisien di depan variabel adalah upah tenaga kerja (Rp Juta). Angka di sisi kanan pertidaksamaan adalah jumlah tenaga kerja (orang per tahun) dikalikan peran penyerapan tenaga kerja pada ekonomi kreatif (persen). 
! PENDIDIKAN PEKERJA SMA SEDERAJAT;
$1.7 *$ KRIYA5 + $1.52 *$ KULINER5 + 1.62*FASHION $5<=15959590 * 0.5905 ;$
$2.51 *$ KRIYA6 + $1.97 *$ KULINER6 + $2.61 *$ FASHION $<=16909690 * 0.5905$

Angka koefisien di depan variabel adalah upah tenaga kerja (Rp Juta). Angka di sisi kanan pertidaksamaan adalah jumlah tenaga kerja (orang per tahun) dikalikan peran penyerapan tenaga kerja pada ekonomi kreatif (persen).

\section{! PENDIDIKAN PEKERJA DIPLOMA KE ATAS;}

$2.99 *$ KRIYA5 + 3.32*KULINER5 + 2.37*FASHION5 $<=15959590 * 0.5905$;

$3.63 *$ KRIYA6 $+2.57 *$ KULINER6 $+1.77 *$ FASHION6 $<=16909690 * 0.5905$;

Angka koefisien di depan variabel adalah upah tenaga kerja (Rp Juta). Angka di sisi kanan pertidaksamaan adalah jumlah tenaga kerja (orang per tahun) dikalikan peran penyerapan tenaga kerja pada ekonomi kreatif (persen).

\section{! STATUS PROFESI WHITE COLLAR;}

$3.34 *$ KRIYA5 + 3.09*KULINER5 + 1.94*FASHION5 $<=15959590 * 0.0691$;

$3.69 *$ KRIYA6 + $2.72 *$ KULINER6 + 3.06*FASHION6 $<=16909690 * 0.0691$;

Angka koefisien di depan variabel adalah upah tenaga kerja (Rp Juta). Angka di sisi kanan pertidaksamaan adalah jumlah tenaga kerja (orang per tahun) dikalikan peran penyerapan tenaga kerja pada ekonomi kreatif (persen).

\section{! STATUS PROFESI BLUE COLLAR; \\ $1.28 *$ KRIYA5 + 1.24*KULINER5 + 1.48*FASHION5 $<=15959590 * 0.9309$; \\ $1.85 *$ KRIYA6 $+1.72 *$ KULINER6 $+2.04 *$ FASHION6 $<=16909690 * 0.9309$;}

Angka koefisien di depan variabel adalah upah tenaga kerja (Rp Juta). Angka di sisi kanan pertidaksamaan adalah jumlah tenaga kerja (orang per tahun) dikalikan peran penyerapan tenaga kerja pada ekonomi kreatif (persen).

KRIYA5 $>=0$;

KRIYA6 $>=0$;

KULINER5 $>=0$;

KULINER6 $>=0$;

FASHION5 $>=0$;

FASHION6 $>=0$;

Model optimalisasi nilai ekspor produk ekonomi kreatif Indonesia jika harga output meningkat sebesar 10 persen disusun fungsi tujuan yang baru sebagai berikut:

! OPTIMALISASI NILAI EKSPOR PRODUK EKONOMI KREATIF INDONESIA TAHUN 2015-2016; HARGA OUTPUT NAIK 10 PERSEN;

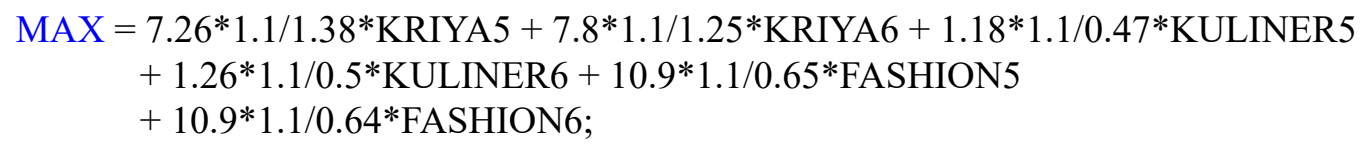

Model optimalisasi nilai ekspor produk ekonomi kreatif Indonesia jika upah tenaga kerja naik sebesar 10 persen disusun fungsi kendala yang baru sebagai berikut:

! MODAL KERJA;

$1.44 * 1.1 *$ KRIYA5 $+1.41 * 1.1 *$ KULINER5 $+1.53 * 1.1 *$ FASHION5 $<=15959590 * 1.59$;

$2.01 * 1.1 *$ KRIYA $6+1.79 * 1.1 *$ KULINER6 $+2.09 * 1.1 *$ FASHION6 $<=16909690 * 2.06$;

! PENDIDIKAN PEKERJA SMP KE BAWAH;

$1.16 * 1.1 *$ KRIYA5 + 1.06*1.1*KULINER5 + 1.44*1.1*FASHION5 < = 15959590*0.5905;

$1.66 * 1.1 *$ KRIYA $6+1.49 * 1.1 *$ KULINER6 $+1.91 * 1.1 *$ FASHION6 $<=16909690 * 0.5905 ;$

! PENDIDIKAN PEKERJA SMA SEDERAJAT;

$1.7 * 1.1 *$ KRIYA5 + 1.52*1.1*KULINER5 + 1.62*1.1*FASHION5 $<=15959590 * 0.5905$

$2.51 * 1.1 *$ KRIYA6 + 1.97*1.1*KULINER6 + 2.61*1.1*FASHION6 < = 16909690*0.5905; 
! PENDIDIKAN PEKERJA DIPLOMA KE ATAS;

$2.99 * 1.1 *$ KRIYA5 $+3.32 * 1.1 *$ KULINER $5+2.37 * 1.1 *$ FASHION5 $<=15959590 * 0.5905$;

$3.63 * 1.1 *$ KRIYA $6+2.57 * 1.1 *$ KULINER6 $+1.77 * 1.1 *$ FASHION $6<=16909690 * 0.5905$;

! STATUS PROFESI WHITE COLLAR;

$3.34 * 1.1 *$ KRIYA $5+3.09 * 1.1 *$ KULINER5 $+1.94 * 1.1 *$ FASHION $5<=15959590 * 0.0691$

$3.69 * 1.1 *$ KRIYA $6+2.72 * 1.1 *$ KULINER $6+3.06 * 1.1 *$ FASHION $6<=16909690 * 0.0691$;

! STATUS PROFESI BLUE COLLAR;

$1.28 * 1.1 *$ KRIYA5 + 1.24*1.1*KULINER5 + 1.48*1.1*FASHION5 <= 15959590*0.9309;

$1.85 * 1.1 *$ KRIYA $6+1.72 * 1.1 *$ KULINER6 $+2.04 * 1.1 *$ FASHION6 $<=16909690 * 0.9309$;

Model optimalisasi nilai ekspor produk ekonomi kreatif Indonesia jika kapasitas pendidikan dinaikkan sebesar 25 persen disusun fungsi kendala yang baru sebagai berikut:

! PENDIDIKAN PEKERJA SMP KE BAWAH;

$1.16 *$ KRIYA $5+1.06 *$ KULINER5 + 1.44*FASHION $5=15959590 * 0.5905 * 0.75$;

$1.66 *$ KRIYA6 + 1.49*KULINER6 + 1.91*FASHION6 < $=16909690 * 0.5905 * 0.75$;

! PENDIDIKAN PEKERJA SMA SEDERAJAT;

$1.7 *$ KRIYA5 + $1.52 *$ KULINER5 + 1.62*FASHION5 $<=15959590 * 0.5905 * 1.25$

$2.51 *$ KRIYA $6+1.97 *$ KULINER6 + 2.61*FASHION6 $<=16909690 * 0.5905 * 1.25$;

! PENDIDIKAN PEKERJA DIPLOMA KE ATAS;

$2.99 *$ KRIYA5 + 3.32*KULINER5 + 2.37*FASHION5 $<=15959590 * 0.5905 * 1.25$;

$3.63 *$ KRIYA $6+2.57 *$ KULINER6 + $1.77 *$ FASHION6 $<=16909690 * 0.5905 * 1.25$;

Model optimalisasi goal programming nilai ekspor produk ekonomi kreatif Indonesia disusun sebagai model awal berikut ini:

! OPTIMALISASI GOAL PROGRAMMING NILAI EKSPOR PRODUK EKONOMI KREATIF INDONESIA TAHUN 2015-2016, MODEL AWAL;

$\mathrm{MIN}=\mathrm{Dmin} ;$

! NILAI EKSPOR EKONOMI KREATIF;

7.26/1.38*KRIYA5 + 7.8/1.25*KRIYA6 + 1.18/0.47*KULINER5 + 1.26/0.5*KULINER6

$+10.9 / 0.65 *$ FASHION $5+10.9 / 0.64 *$ FASHION6

+ Dmin - Dplus $>=19.36+19.99$;

! MODAL KERJA;

$1.44 *$ KRIYA5 + 1.41*KULINER5 + 1.53*FASHION5 >= 15959590*1.59;

$2.01 *$ KRIYA6 + $1.79 *$ KULINER6 + 2.09*FASHION6 >= 16909690*2.06;

! PENDIDIKAN PEKERJA SMP KE BAWAH;

$1.16 *$ KRIYA5 + 1.06*KULINER5 + 1.44*FASHION5 $>=15959590 * 0.5905$;

$1.66 *$ KRIYA $6+1.49 *$ KULINER6 + 1.91*FASHION6 > $=16909690 * 0.5905$;

! PENDIDIKAN PEKERJA SMA SEDERAJAT;

$1.7 *$ KRIYA5 + 1.52*KULINER5 + 1.62*FASHION5 $>=15959590 * 0.5905$;

$2.51 *$ KRIYA6 $+1.97 *$ KULINER6 $+2.61 *$ FASHION6 $>=16909690 * 0.5905$;

! PENDIDIKAN PEKERJA DIPLOMA KE ATAS;

$2.99 *$ KRIYA5 + 3.32*KULINER5 + 2.37*FASHION5 $>=15959590 * 0.5905$;

$3.63 *$ KRIYA6 + $2.57 *$ KULINER6 + 1.77*FASHION6 $>=16909690 * 0.5905$; 


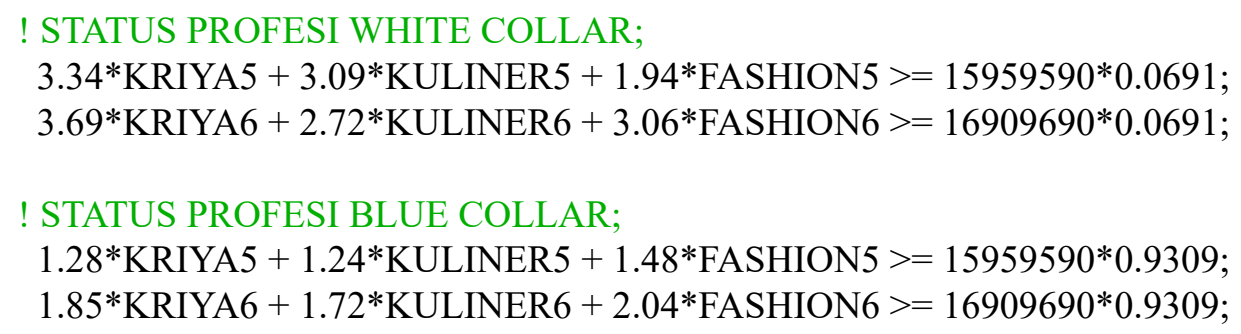

Model optimalisasi goal programming nilai ekspor produk ekonomi kreatif Indonesia untuk harga jual output naik 10 persen yang baru disusun sebagai berikut:

! OPTIMALISASI NILAI EKSPOR PRODUK EKONOMI KREATIF INDONESIA TAHUN 2015-2016, HARGA JUAL OUTPUT NAIK SEBESAR 10 PERSEN;

! NILAI EKSPOR PRODUK EKONOMI KREATIF;

7.26*1.1/1.38*KRIYA5 + 7.8*1.1/1.25*KRIYA6 + 1.18*1.1/0.47*KULINER5

$+1.26 * 1.1 / 0.5 *$ KULINER6 + 10.9*1.1/0.65*FASHION5 + 10.9*1.1/0.64*FASHION6

+ Dmin - Dplus $=19.36+19.99$;

Angka pada sisi kanan adalah nilai ekspor tahun 2015 dan 2016 dalam miliar dollar AS.

Model optimalisasi goal programming nilai ekspor produk ekonomi kreatif Indonesia untuk upah tenaga kerja naik 10 persen yang baru disusun sebagai berikut:

! OPTIMALISASI GOAL PROGRAMMING NILAI EKSPOR PRODUK EKONOMI KREATIF INDONESIA TAHUN 2015-2016, UPAH PEKERJA NAIK 10 PERSEN;

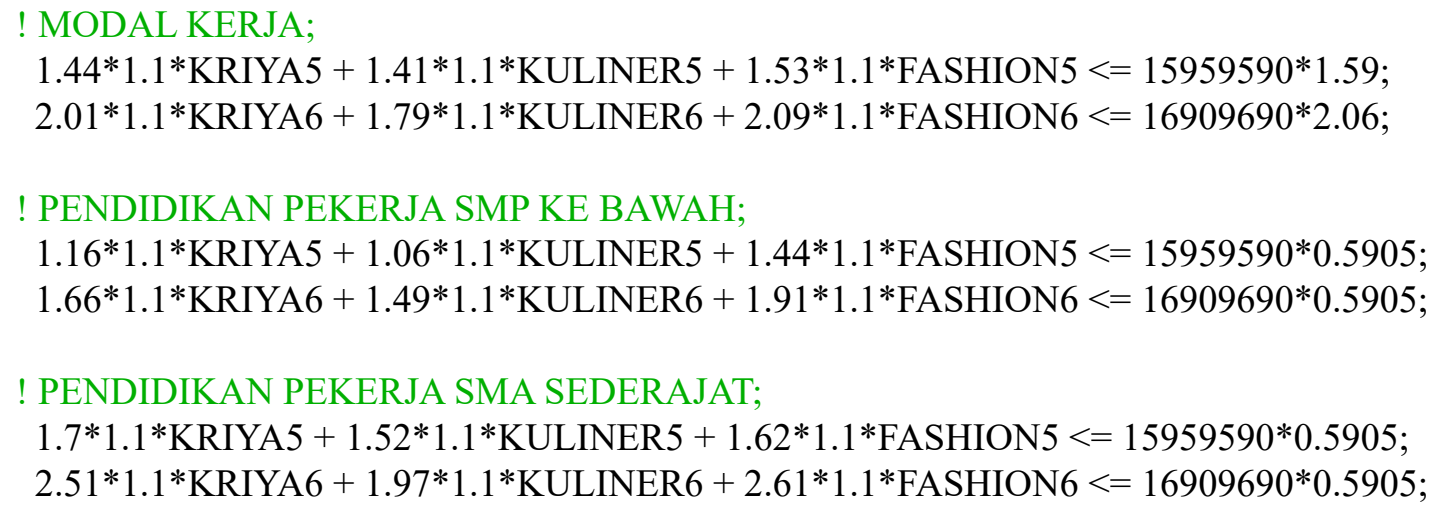


$1.85 * 1.1 *$ KRIYA6 + 1.72*1.1*KULINER6 + 2.04*1.1*FASHION6 <= 16909690*0.9309;

Model optimalisasi goal programming nilai ekspor produk ekonomi kreatif Indonesia untuk kapasitas pendidikan naik 10 persen yang baru disusun sebagai berikut:

! OPTIMALISASI GOAL PROGRAMMING NILAI EKSPOR PRODUK EKONOMI KREATIF INDONESIA TAHUN 2015-2016, KAPASITAS PENDIDIKAN NAIK 25\%;

! PENDIDIKAN PEKERJA SMP KE BAWAH;

$1.16 *$ KRIYA5 + 1.06*KULINER5 + 1.44*FASHION5 $<=15959590 * 0.5905 * 0.75$;

$1.66 *$ KRIYA $6+1.49 *$ KULINER6 + 1.91*FASHION6 $<=16909690 * 0.5905 * 0.75$;

! PENDIDIKAN PEKERJA SMA SEDERAJAT;

$1.7 *$ KRIYA5 + $1.52 *$ KULINER5 + 1.62*FASHION5 $<=15959590 * 0.5905 * 1.25$

$2.51 *$ KRIYA $6+1.97 *$ KULINER $6+2.61 *$ FASHION6 $<=16909690 * 0.5905 * 1.25$;

! PENDIDIKAN PEKERJA DIPLOMA KE ATAS;

$2.99 *$ KRIYA5 + 3.32*KULINER5 + 2.37*FASHION5 $<=15959590 * 0.5905 * 1.25$;

$3.63 *$ KRIYA $6+2.57 *$ KULINER6 + $1.77 *$ FASHION6 $<=16909690 * 0.5905 * 1.25$;

\section{HASIL DAN PEMBAHASAN}

\section{Sensitivitas optimalisasi nilai ekspor}

Temuan pertama, yaitu Tabel 2 menunjukkan bahwa nilai tujuan yang terbesar dari nilai ekspor ekonomi kreatif diperoleh skenario ketika harga output produk ekonomi kreatif ekspor mengalami peningkatan. Temuan kedua, nilai tujuan mengalami penurunan disebabkan oleh skenario peningkatan upah tenaga kerja. Penurunan dari upah tenaga kerja tersebut mempunyai akibat yang lebih besar dalam menurunkan nilai tujuan dibandingkan akibat yang terjadi apabila dilakukan simulasi peningkatan harga output nilai tujuan.

Tabel 2. Hasil Sensitivitas Optimalisasi Nilai Ekspor Produk Ekonomi Kreatif di Indonesia Tahun 2015=2016 Global Optimal

\begin{tabular}{lllll}
\hline Item & Model Awal & $\begin{array}{l}\text { Harga Output } \\
\text { Naik 10\% }\end{array}$ & $\begin{array}{l}\text { Upah Tenaga } \\
\text { Kerja Naik 10\% }\end{array}$ & $\begin{array}{l}\text { Kapasitas } \\
\text { Pendidikan Naik } \\
10 \%\end{array}$ \\
\hline Nilai tujuan & $0.1603597 \mathrm{E}+08$ & $0.1763957 \mathrm{E}+08$ & $0.1457816 \mathrm{E}+08$ & $0.1603597 \mathrm{E}+08$ \\
\hline Infeasibilities & 0.000000 & 0.000000 & 0.000000 & 0.000000 \\
\hline Iterasi & 4 & 4 & 4 & 4 \\
\hline Kriya5 & 0.000000 & 0.000000 & 0.000000 & 0.000000 \\
\hline Kriya6 & 0.000000 & 0.000000 & 0.000000 & 0.000000 \\
\hline Kuliner5 & 0.000000 & 0.000000 & 0.000000 & 0.000000 \\
\hline Kuliner6 & 0.000000 & 0.000000 & 0.000000 & 0.000000 \\
\hline Fashion5 & 568457.6 & 568457.6 & 516779.6 & 568457.6 \\
\hline Fashion6 & 381849.5 & 381849.5 & 347135.9 & 381849.5 \\
\hline
\end{tabular}

Sumber: Hasil Pengolahan Data, 2019.

Pada penelitian ini diperoleh temuan yang menarik sebagai temuan yang ketiga, yaitu peningkatan kapasitas pendidikan tidak mempengaruhi perubahan nilai tujuan pada model ekonomi kreatif. Kondisi yang seperti ini terlihat aneh, karena berbeda dengan anggapan bahwa pada tingkat pendidikan yang semakin tinggi akan ditemukan peningkatan kreativitas.

Temuan keempat yang menarik pada Tabel 2 adalah model menunjukkan bahwa produk fashion merupakan produk yang efisien dibandingkan memproduksi ekspor produk kriya dan produk kuliner, baik untuk posisi tahun 2015 dan 2016. Temuan ini sejalan dengan kondisi realitas besarnya peran produk fashion pada ekspor ekonomi kreatif Indonesia.

Temuan kelima diketahui bahwa jumlah produk fashion tahun 2015 dan 2016 tetap sama pada model 
awal, kenaikan harga jual output, maupun ketika kapasitas pendidikan tenaga kerja yang meningkat. Temuan keenam penting untuk dicermati adalah kinerja jumlah ekspor produk fashion justru menurun ketika upah tenaga kerja mengalami kenaikan, yaitu baik pada model awal, maupun ketika harga jual output meningkat serta ketika kapasitas pendidikan mengalami peningkatan. Penurunan kinerja jumlah ekspor pada produk fashion yang seperti ini tidaklah sama dengan perkembangan kinerja nilai ekspor produk ekonomi kreatif yang justru menunjukkan peningkatan pada periode tahun 2015-2016.

Tabel 3. Hasil Reduced Cost Sensitivitas Optimalisasi Nilai Ekspor Produk Ekonomi Kreatif di Indonesia Tahun 2015=2016 Global Optimal

\begin{tabular}{lllll}
\hline Item & Model Awal & $\begin{array}{l}\text { Harga Output } \\
\text { Naik 10\% }\end{array}$ & $\begin{array}{l}\text { Upah Tenaga } \\
\text { Kerja Naik 10\% }\end{array}$ & $\begin{array}{l}\text { Kapasitas } \\
\text { Pendidikan Naik } \\
25 \%\end{array}$ \\
\hline Kriya5 & 23.60987 & 25.97085 & 23.60987 & 23.60987 \\
\hline Kriya6 & 14.29768 & 15.72745 & 14.29768 & 14.29768 \\
\hline Kuliner5 & 24.19912 & 26.61903 & 24.19912 & 24.19912 \\
\hline Kuliner6 & 12.61889 & 13.88078 & 12.61889 & 12.61889 \\
\hline Fashion5 & 0.000000 & 0.000000 & 0.000000 & 0.000000 \\
\hline Fashion6 & 0.000000 & 0.000000 & 0.000000 & 0.000000 \\
\hline Sumber: Hasil Pengolahan Data, 2019. & & &
\end{tabular}

Dengan kata lain, ketika harga ekspor produk fashion mengalami peningkatan, maka jumlah ekspor produk fashion mengalami penurunan sekalipun kondisi aktual nilai ekspor fashion mengalami peningkatan. Fenomena yang seperti ini menunjukkan bahwa perilaku permintaan pada ekspor produk ekonomi kreatif lebih menonjol dibandingkan perilaku penawaran. Perilaku permintaan menunjukkan bahwa ketika harga jual produk ekonomi kreatif meningkat, maka jumlah permintaan ekspor produk ekonomi kreatif menurun.

Sebaliknya, perilaku penawaran menunjukkan bahwa ketika harga jual produk ekonomi kreatif meningkat, maka jumlah penawaran produk ekonomi kreatif justru mengalami peningkatan. Temuan ini menunjukkan indikasi bahwa peran tarikan permintaan ekspor dari pembeli di luar negeri jauh lebih menentukan dibandingkan usaha dari sisi penawaran ekspor. Dengan kata lain adalah fenomena meningkatkan ekspor produk ekonomi kreatif adalah fenomena demand side dibandingkan peran supply side.

Tabel 3 menunjukkan implikasi dari Tabel 2, yaitu efisiensi produksi ekspor ekonomi kreatif ditunjukkan pada subsektor fashion tahun 2015 dan 2016. Apabila produk kriya atau pun produk kuliner dipaksakan untuk diekspor, maka setiap satuan peningkatan produksi ekspor produk kriya dan kuliner akan berdampak pada penurunan nilai tujuan sebesar angka yang tercantum pada reduced cost Tabel 3.

Berdasarkan hasil pengolahan data dengan menggunakan model simulasi di atas menunjukkan bahwa pemerintah sebaiknya mengoptimalkan ekspor produk fashion saja dibandingkan meningkatkan ekspor produk kriya dan produk kuliner. Sementara itu peningkatan ekspor produk kriya dan produk kuliner pada tahun 2015 berdampak lebih besar dalam menurunkan nilai tujuan dibandingkan tahun 2016.

\section{Sensitivitas goal programming}

Hasil simulasi pengolahan data pada Tabel 4 menunjukkan bahwa optimalisasi goal programming untuk tujuan meningkatkan ekspor produk ekonomi kreatif tercapai dengan cara meningkatkan ekspor produk subsektor fashion pada tahun 2016 untuk ketiga skenario. Temuan ini sejalan dengan temuan yang diperoleh berdasarkan Tabel 2. Ketiga skenario pada Tabel 4 tersebut berupa skenario peningkatan harga output sebesar 10 persen, skenario upah tenaga kerja meningkat sebesar 10 persen, dan skenario kapasitas pendidikan meningkat sebesar 10 persen.

Tabel 4. Hasil Sensitivitas Goal Programming Optimalisasi Nilai Ekspor Produk Ekonomi Kreatif di Indonesia Tahun 2015=2016 Global Optimal

\begin{tabular}{lllll}
\hline Item & Model Awal & $\begin{array}{l}\text { Harga Output } \\
\text { Naik 10\% }\end{array}$ & $\begin{array}{l}\text { Upah Tenaga } \\
\text { Kerja Naik 10\% }\end{array}$ & $\begin{array}{l}\text { Kapasitas } \\
\text { Pendidikan Naik } \\
10 \%\end{array}$ \\
\hline Nilai tujuan & 0.000000 & 0.000000 & 0.000000 & 0.000000 \\
\hline Infeasibilities & 0.000000 & 0.000000 & 0.000000 & 0.000000 \\
\hline
\end{tabular}




\begin{tabular}{lllll}
\hline Item & Model Awal & $\begin{array}{l}\text { Harga Output } \\
\text { Naik 10\% }\end{array}$ & $\begin{array}{l}\text { Upah Tenaga } \\
\text { Kerja Naik 10\% }\end{array}$ & $\begin{array}{l}\text { Kapasitas } \\
\text { Pendidikan Naik } \\
10 \%\end{array}$ \\
\hline Iterasi & 2 & 1 & 1 & 1 \\
\hline Dmin & 0.000000 & 0.000000 & 0.000000 & 0.000000 \\
\hline Kriya5 & 0.000000 & 0.000000 & 0.000000 & 0.000000 \\
\hline Kriya6 & 0.000000 & 0.000000 & 0.000000 & 0.000000 \\
\hline Kuliner5 & 0.000000 & 0.000000 & 0.000000 & 0.000000 \\
\hline Kuliner6 & 0.000000 & 0.000000 & 0.000000 & 0.000000 \\
\hline Fashion5 & $0.1658546 \mathrm{E}+08$ & 0.000000 & 0.000000 & 0.000000 \\
\hline Fashion6 & $0.1666697 \mathrm{E}+08$ & 2.100417 & 2.310459 & 2.310459 \\
\hline Dplus & 0.000000 & 0.000000 & 0.000000 & 0.000000 \\
\hline Sumber: Hasil Pengolahan Data, 2019. & & &
\end{tabular}

Pada waktu simulasi pengolahan data pada penelitian ini telah dilakukan perubahan-perubahan angka di sebelah kanan persamaan (right hand side) dengan memasukkan optimalisasi goal programming pada persamaan tenaga kerja, namun pemodelan yang cocok adalah pada model dengan tujuan meningkatkan ekspor produk ekonomi kreatif dibandingkan dengan model meningkatkan penyerapan tenaga kerja. Hal ini menjadi temuan ketujuh, yaitu pembangunan ekonomi kreatif lebih optimal untuk tujuan meningkatkan ekspor produk ekonomi kreatif dibandingkan untuk tujuan meningkatkan penyerapan tenaga kerja. Temuan yang seperti ini memperkuat keyakinan bahwa ekonomi kreatif berawal dari kinerja kreativitas, dimana faktor kreativitas pada posisi perkembangan teknologi ekonomi kreatif di Indonesia secara aktual belumlah pada tahap dapat secara optimal dijadikan sebagai instrument meningkatkan penyerapan tenaga kerja secara massif dibandingkan untuk mengoptimalkan tujuan meningkatkan ekspor produk ekonomi kreatif.

Tabel 5 memperkuat temuan bahwa reduced cost dijumpai pada minimalisasi tujuan Dmin dibandingkan Dplus. Sementara itu reduced cost pada model goal programming kinerja ekspor produk kriya, produk kuliner, dan produk fashion sebesar nol untuk ketiga skenario.

Tabel 5. Hasil Reduced Cost Sensitivitas Goal Programming Optimalisasi Nilai Ekspor Produk Ekonomi Kreatif di Indonesia Tahun 2015=2016 Global Optimal

\begin{tabular}{lllll}
\hline Item & Model Awal & $\begin{array}{l}\text { Harga Output } \\
\text { Naik 10\% }\end{array}$ & $\begin{array}{l}\text { Upah Tenaga } \\
\text { Kerja Naik 10\% }\end{array}$ & $\begin{array}{l}\text { Kapasitas } \\
\text { Pendidikan Naik } \\
25 \%\end{array}$ \\
\hline Dmin & 1.000000 & 1.000000 & 1.000000 & 1.000000 \\
\hline Kriya5 & 0.000000 & 0.000000 & 0.000000 & 0.000000 \\
\hline Kriya6 & 0.000000 & 0.000000 & 0.000000 & 0.000000 \\
\hline Kuliner5 & 0.000000 & 0.000000 & 0.000000 & 0.000000 \\
\hline Kuliner6 & 0.000000 & 0.000000 & 0.000000 & 0.000000 \\
\hline Fashion5 & 0.000000 & 0.000000 & 0.000000 & 0.000000 \\
\hline Fashion6 & 0.000000 & 0.000000 & 0.000000 & 0.000000 \\
\hline Dplus & 0.000000 & 0.000000 & 0.000000 & 0.000000 \\
\hline
\end{tabular}

Sumber: Hasil Pengolahan Data, 2019.

\section{Pembahasan}

Temuan pertama adalah nilai tujuan yang terbesar dari nilai ekspor ekonomi kreatif diperoleh skenario ketika harga output produk ekonomi kreatif ekspor mengalami peningkatan. Kondisi seperti ini mempunyai implikasi bahwa ekspor produk ekonomi kreatif respons terhadap kenaikan harga jual ekspor. Akan tetapi yang ditemukan pada kinerja ekspor produk ekonomi kreatif lebih merupakan sebagai fenomena tarikan demand side dibandingkan supply side, maka pemerintah perlu lebih berperan untuk memperkuat posisi tawar pada kelembagaan para eksportir produk ekonomi kreatif, misalnya dengan memperkuat peran asosiasi eksportir produk ekonomi kreatif Indonesia.

Temuan kedua adalah nilai tujuan mengalami penurunan disebabkan oleh skenario peningkatan upah tenaga kerja. Implikasi dari temuan ini adalah faktor daya saing ekspor produk ekonomi kreatif Indonesia terletak pada 
pemanfaatan upah tenaga kerja lebih murah, dimana peningkatan kebijakan upah minimum pada produk ekonomi kreatif berdampak menurunkan jumlah ekspor produk ekonomi kreatif Indonesia.

Temuan ketiga adalah peningkatan kapasitas pendidikan tidak mempengaruhi perubahan nilai tujuan pada model ekonomi kreatif. Implikasi dari temuan ini menunjukkan bahwa ekspor produk ekonomi kreatif tidaklah otomatis meningkat apabila tingkat pendidikan tenaga kerja ditingkatkan, melainkan perlu peningkatan kreativitas. Pada kondisi aktual dewasa ini pada pembangunan ekonomi kreatif ditemukan bahwa antara kreativitas dan peningkatan tingkat pendidikan tenaga kerja tidaklah senantiasa berbanding lurus.

Temuan keempat adalah produk fashion merupakan produk yang efisien dibandingkan memproduksi ekspor produk kriya dan produk kuliner. Implikasi dari temuan ini adalah untuk tujuan meningkatkan ekspor produk ekonomi kreatif, maka pemerintah perlu memprioritaskan ekspor produk fashion dibandingkan produk kriya dan produk kuliner. Temuan ini menguatkan temuan dari Fathurrahman dan Huseini (2016) yang menuliskan bahwa ekonomi kreatif di Indonesia yang memiliki keunggulan kompetitif belum dioptimalkan, yaitu: kuliner dan fashion ekonomi kreatif.

Temuan kelima adalah jumlah produk fashion tahun 2015 dan 2016 tetap sama pada model awal, kenaikan harga jual output, maupun ketika kapasitas pendidikan tenaga kerja yang meningkat. Temuan keenam adalah kinerja jumlah ekspor produk fashion justru menurun ketika upah tenaga kerja mengalami kenaikan. Temuan kelima dan temuan keenam ini telah memperkuat temuan kedua.

Temuan ketujuh adalah pembangunan ekonomi kreatif lebih optimal untuk tujuan meningkatkan ekspor produk ekonomi kreatif dibandingkan untuk tujuan meningkatkan penyerapan tenaga kerja, yaitu dengan memproduksi produk fashion. Temuan ini mempunyai implikasi bahwa tujuan meningkatkan deisa ekspor dari produk ekonomi kreatif adalah lebih penting dibandingkan menjadikan pembangunan ekonomi kreatif sebagai instrument untuk meningkatkan penyerapan tenaga kerja.

Temuan kedelapan. Volume ekspor produk kriya sebesar 1,38 juta ton tahun 2015 dan sebesar 1,25 juta ton tahun 2016. Volume ekspor produk fashion sebesar 0,65 juta ton tahun 2015 dan sebesar 0,64 juta ton tahun 2016. Volume ekspor produk kuliner sebesar 0,47 juta ton tahun 2015 dan sebesar 0,50 juta ton tahun 2016. Berdasarkan pemodelan skenario awal, skenario harga output naik 10 persen, skenario upah tenaga kerja naik 10 persen, dan skenario kapasitas pendidikan naik 10 persen diperoleh volume ekspor optimal untuk produk kriya dan produk kuliner sebesar nol juta ton tahun 2015 dan tahun 2016, sehingga volume ekspor produk Kriya dan produk kuliner tidak optimal atau kelebihan volume ekspor. Kemudian volume ekspor produk fashion yang optimal sebesar 0,57 juta ton tahun 2015 dan sebesar 0,38 juta ton tahun 2016 untuk skenario model awal, skenario harga output naik 10 persen, dan skenario kapasitas pendidikan naik 10 persen. Akibatnya adalah terjadi inefisiensi berupa kelebihan volume ekspor produk fashion sebesar 14,04 persen tahun 2015 dan sebesar 68,42 persen tahun 2016. Volume ekspor produk fashion yang optimal sebesar 0,52 ribu ton tahun 2015 dan sebesar 0,38 juta ton tahun 2016 untuk skenario upah tenaga kerja naik sebesar 10 persen, sehingga terajadi inefisiensi atau kelebihan volume ekspor produk fashion sebesar 25 persen tahun 2015 dan sebesar 82,86 persen tahun 2016. Kelebihan volume ekspor produk ekonomi kreatif Indonesia tersebut menjadi indikasi dari keberadaan dayasaing ekspor produk.

Berdasarkan hasil dan pembahasan; Ekspor produk ekonomi kreatif respons terhadap kenaikan harga jual ekspor, namun perkembangan perilaku ekspor produk ekonomi kreatif lebih besar pada perilaku permintaan jumlah ekspor produk ekonomi kreatif dibandingkan perilaku penawaran ekspor produk ekonomi kreatif. Faktor daya saing ekspor produk ekonomi kreatif Indonesia terletak pada pemanfaatan upah tenaga kerja lebih murah, dimana peningkatan kebijakan upah minimum pada produk ekonomi kreatif berdampak menurunkan jumlah ekspor produk ekonomi kreatif Indonesia. Ekspor produk ekonomi kreatif tidaklah otomatis meningkat, apabila tingkat pendidikan tenaga kerja ditingkatkan, melainkan berasal dari peningkatan kreativitas. Produk fashion merupakan produk yang efisien dibandingkan memproduksi ekspor produk kriya dan produk kuliner. Akan tetapi fenomena kelebihan ekspor produk ekonomi kreatif dibandingkan model optimalisasi menjadi indikasi tentang keberadaan dayasaing produk ekonomi kreatif Indonesia. Pembangunan ekonomi kreatif lebih optimal untuk tujuan meningkatkan ekspor produk ekonomi kreatif dibandingkan untuk tujuan meningkatkan penyerapan tenaga kerja, yaitu dengan memproduksi produk fashion. 


\section{KESIMPULAN}

Berdasarkan kesimpulan; Pemerintah perlu memperkuat kelembagaan asosiasi ekspor produk ekonomi kreatif Indonesia supaya posisi tawar dari kekuatan demand side importir dapat diimbangi oleh kekuatan tawar asosiasi. Pemerintah perlu melakukan perbaikan produktivitas tenaga kerja produsen produk ekonomi kreatif Indonesia supaya daya saing ekspor produk ekonomi kreatif Indonesia tidak mudah melemah, apabila para pekerja ekonomi kreatif mendapat kenaikan upah. Selain pemerintah perlu memprioritaskan ekspor produk fashion, pemerintah perlu melakukan kajian secara lebih mendalam untuk memperbaiki efisiensi produksi produk kriya dan produk kuliner supaya dayasaing kedua produk tersebut meningkat sehingga pembangunan ekonomi kreatif ekspor tidak lagi terlalu bergantung pada kinerja ekspor produk fashion. Pemerintah perlu meningkatkan produk penciptaan pengetahuan yang dapat lebih meningkatkan kreativitas tenaga kerja produk kreatif, sehingga ekonomi kreatif juga dapat dijadikan sebagai instrument untuk meningkatkan penyerapan tenaga kerja.

\section{DAFTAR PUSTAKA}

Badan Ekonomi dan Kreatif [BEKRAF]. (2018). Data Statistik dan Hasil Survey Ekonomi Kreatif. Kerjasama Badan Ekonomi Kreatif dan Badan Pusat Statistik, Jakarta.

Badan Ekonomi dan Kreatif [BEKRAF]. (2017). Data Statistik dan Hasil Survey Ekonomi Kreatif. Kerjasama Badan Ekonomi Kreatif dan Badan Pusat Statistik, Jakarta.

Badan Ekonomi dan Kreatif [BEKRAF]. (2017). Ekspor Ekonomi Kreatif 2010-2016. Kerjasama Badan Ekonomi Kreatif dan Badan Pusat Statistik, Jakarta.

Badan Ekonomi dan Kreatif [BEKRAF]. (2017). Upah Tenaga Kerja Ekonomi Kreatif 2011-2016. Kerjasama Badan Ekonomi Kreatif dan Badan Pusat Statistik, Jakarta.

Belete, W. (2016). Policy Modalities for Support of Ethiopia's Creative Industries. The African Journal of Information and Communication (AJIC), 19, 59-77.

Daubaraite, U. and G. Startiene. (2015). Creative industries Impact on National Economy in Regard to Sub-sector. $2^{\text {th }}$ International Scientific Conference Economics and Management-2015 (ICEM2015), Procedia-Social and Behavioral Sciences 213(2015)129-134, Elsevier.

Dunska, M. and A. Marcinkevica. (2017). Situation and Development Opportunities of Creative Industries Companies in Latvia. Eurepean Research Studies Journal, Vol.XX, Issue 3A, 2017, pp:96-114.

Fathurrahman, H. and M. Huseini. (2018). Mapping of Regional Economic Potential Based on Creative Economy to Support Creation of Regional Competitiveness. Knowledge and Social Transformation, vol. 2018.

Heizer, Jay and Render Barry. (2011). Operations Management. Prentice Hall. New Jersey.

Kontrimiene, V. and B. Melnikas. (2017). Creative Industries: Development Process Under Contemporary Conditions of Globalization. Business, Management and Education, 15(1):109-126.

Lindo Systems Inc. (2008). LINGO User's Guide. Lindo System Inc., Chicago.

Potts, J.D. (2009). Why Creative Industries Matter to Economic Evolution. Economics of Innovation and New Technology, 18(7-8), pp.663-673.

Septri, W. dan I. Krisnadi. (2019). Pemanfaatan Big Data dalam Perkembangan Ekonomi dan Bisnis di Indonesia. Jurnal Manajemen Bisnis dan ICT Universitas Mercu Buana Jakarta, Januari 2019.

Skavronska, I.V. (2017). Creative Industries in Ukraine: Analysis and Prospects of the Development. Economics and Sociology, Vol. 10, No. 2, pp.87-106.

Sukma, M., D. Hartono, and S. Prihawantoro. (2008). The Impacts Analysis of Creative-Products Export on the Economy. Jurnal Ekonomi dan Kebijakan (JEJAK), Vol 11(1) (2008):92-107. 